\title{
obituary
}

\section{O. M. B. Bulman}

Professor Oliver Meredith Boone BULMAN, FRS, who died at the age of 71 on February 18 was generally recognised as the leading authority on the graptolites, the group of colonial organisms which came into being, flourished and died out in the Lower Palaeozoic.

Bulman was trained as a geologist at Imperial College where he remained to carry out research under the direction of W. W. Watts. Among fellow students investigating various aspects of the Palaeozoic rocks of Britain at that time were Stubblefield, Whittard, Mitchell, Howell and David Williams all of whom were to hold posts of distinction.

Bulman has recorded that he was first attracted to the graptolites by beautifully preserved specimens of Dictyonema in the Sineton shales, on which he and Stubblefield were working; and he took this as the subject for his first palaeontological investigations. From the first, he concentrated on well preserved material which he prepared and figured with great skill. In this way he was able to establish details of the external form, and in many instances, of the internal siructure. With this new information he was particularly sucessful in elucidating the early stages of the growth of graptolites. When he completed his tenure of a Senior Studentship of the Royal Commission for the Exhibition of 1851, it was said that only a man of exceptional talent could have produced the results he had by then achieved.

After holding demonstratorships in the Zoology and Geology Departments at Imperial College, Bulman was appointed in 1931 to a post in the Sedgwick Museum where he remained for the rest of his academic life. In 1945 he became Reader in Palaeontology and in 1955 was appointed Woodwardian Professor of Geology. In 1945 he was elected a Fellow of Sydney Sussex College. He was President of Section C of the British Association in 1959 and received in succession the Lyell Fund and the Lyell Medal from the Geological Society of which he was President from 1962-64. He was connected with the Geological Magazine either as Ediior or its advisor for 40 years.

Throughout his career the study of graptolites remained his principle scientific concern. He continued as he had begun with a series of meticulous accounts which covered graptolites not only from Britain, but from North America, Scandinavia and Asia. He acquired an immense knowledge of their worldwide distribution which he put to use in his discussions of their mode of life and of the steps by which the graptolites evolved. He expressed his conclusions cautiously leaving the reader in no doubt where uncertainity existed.

Whatever the future may hold Bulman's part in the elucidation of the graptolites is likely to remain as a landmark in studies of Palaeozoic life.

\section{Announcements}

\section{Appointments}

The following are the members of the government select committee on science and technology: R. Brown, R. Carter, J. Cunningham, N. McFarlane, A. Fletcher, D. Ginsberg, F. Hooley, r. Ledbetter, I. Lloyd, A. Neave, A. Palmer, N. Tebbit, C. Tyelar and $K$. Warren.

D. J. Lyons has been appointed a member of the Science Research Council.

E. J. Denton has been appointed Director of the Plymouth Laboratory and Secretary of the Marine Biological Association of the United Kingdom.

G. R. Bainbridge has been appointed to the Chair of Energy Studies at the University of Newcastle upon Tyne.

I. R. Smith has been appointed to a chair in the Department of Electronic and Electrical Engineering at Loughborough University of Technology.

R. N. Parkins has been appointed to the William Cochrane Chair of Metallurgy and Engineering Materials at the University of Newcastle upon Tyne.

C. McGreavy has been appointed to a second chair in the Department of Chemical Engineering at the University of Leeds.

G. T. Stevenson has been appointed a professor of the University of Southampton.

D. K. Bailey has been appointed Professor of Geology at the University of Reading.

The following have been elected Foreign Members of the Royal Society: $\mathbf{R}$. Dulbecco, G. H. Hitchings, G. P. S. Occhialini and $\mathbf{J}-\mathbf{P}$ Serre.

The following have been elected Members of the National Academy of Sciences: R. D. Alexander, E. Anders, R. C. Atkinson, K. F. Austen, W. O. Aydelotte, J. W. Backus, D. Baltimore, L. M. Beidler, F. R. Boyd, Jr, M. K. Brakke, E. Braunwald, W. R. Briggs, T. C. Bruice, S. J.
Buchsbaum, O. L. Chapman, J. A. Clements, G. L. Closs, W. G. Cochran, C. C. Cockerham, L. J. Cronbach, H. W. Davenport, C. A. Finch, W. H. Flygare, H. L. Fraenkel-Conrat, R. Freedman, J. Furth, D. C. Gajdusek, E. P. Geiduschek, I. Giaever, M. Gibbs, R. R. Gilruth, H. H. Goldstine, L. A. Goodman, R. W. Gould, K. I. Greisen, J. Gross, R. C. L. Guillemin, C. F. Hockett, H. S. Houthakker, F. S. Hulse, L. Hurwicz, J. Hurwicz, J. D. Isaacs, A. Javan, E. V. Jensen, E. R. Kandel, B. Kok, N. M. Kroll, H. D. Lasswell, P. F. Lazarsfeld, W. Leontief, E. B. Leopold, A. P. Lerner, R. Levins, D. L. Lindsley, Jr, F. J. Low, C. R. Lynds, R. S. MacNeish, J. L. Margrave, C. F. Mosteller, G. D. Mostow, H. J. MiillerEberhard, H. N. Munro, T. M. Newcomb, A. B. Novikoff, J. P. Ostriker, C. K. N. Patel, R. G. Pearson, W. G. Pfann, L. J. Postman, D. M. Prescott, C. L. Prosser, A. E. Puckett, S. Ratner, W. H. Riker, H. Ris, H. E. Robbins, A. Robinson, G. W. Salisbury, R. Schmid, T. W. Schultz, W. R. Sears, 